\title{
PENGARUH MODEL PEMBELAJARAN BERBASIS PROYEK TERHADAP HASIL BELAJAR IPA
}

\author{
Gusti Ayu Made Dwiyani Putri \\ Program Studii Pendidikan Guru Sekolah Dasar, Universitas Pendidikan Ganesha \\ gusti.ayu.made.dwiya@undiksha.ac.id \\ Ni Wayan Rati \\ Program Studii Pendidikan Guru Sekolah Dasar, Universitas Pendidikan Ganesha \\ niwayan.rati@undiksha.ac.id \\ Luh Putu Putrini Mahadewi \\ Program Studii Pendidikan Guru Sekolah Dasar, Universitas Pendidikan Ganesha \\ lpp-mahadewi@undiksha.ac.id
}

\begin{abstract}
Abstrak
Permasalahan ini berdasarkan pada beberapa permasalahan: 1) Pembelajaran IPA masih berpusat pada guru. 2) Kurangnya variasi model atau metode pembelajaran. 3) Hasil belajar IPA siswa di Gugus I Kecamatan Seririt sebagian besar masih dibawah KKM. Penelitian ini bertujuan untuk mengetahui perbedaan hasil belajar IPA antara kelompok siswa yang dibelajarkan menggunakan model Pembelajaran Berbasis Proyek dan kelompok siswa yang tidak dibelajarkan menggunakan model Pembelajaran Berbasis Proyek pada siswa kelas V di Gugus I Kecamatan Seririt tahun pelajaran 2017/2018. Jenis penelitian ini adalah penelitian eksperimen semu, dengan desain Post Test Only Control Group Design. Populasi penelitian ini adalah seluruh siswa kelas V di Gugus I Kecamatan Seririt tahun pelajaran 2017/2018 yang berjumlah 128 orang. Sampel penelitian ini yaitu siswa kelas V SD N 1 Kalianget sebagai kelompok eksperimen dan siswa kelas V SD N 2 Joanyar sebagai kelompok kontrol. Pengumpulan data dilakukan dengan metode tes. Instrument tes hasil belajar IPA yang digunakan dalam bentuk tes obyektif. Data yang diperoleh dianalisis menggunakan analisis statistik deskriptif dan statistik inferensial. Berdasarkan hasil perhitungan uji-t diperoleh $t_{\text {hit }}=4,51$ dan $t_{\text {tab }}$ (pada taraf signifikansi $5 \%)=2,002$. Sehingga didapatkan $t_{\text {hit }}>t_{\text {tab }}$ yang berarti bahwa terdapat perbedaan yang signifikan hasil belajar IPA antara antara kelompok siswa yang dibelajarkan menggunakan model Pembelajaran Berbasis Proyek dan kelompok siswa yang tidak dibelajarkan menggunakan model Pembelajaran Berbasis Proyek. Rata- rata hasil belajar IPA siswa kelompok eksperimen 21,9 dan kelompok kontrol 15,45, jadi dapat disimpulkan model Pembelajaran Berbasis Proyek berpengaruh positif terhadap hasil belajar IPA siswa kelas V.
\end{abstract}

Kata-kata kunci: hasil belajar IPA, $P B L$

\begin{abstract}
This research is based on several problems as follow. 1) Sains learning outcome is still teacher-centered. 2) Lack of models variation or learning method. 3) Result of learning Sains learning outcome students belonging to Cluster I of Seririt Sub-district which mostly still under KKM. The purpose of this aimed to identify the difference of the Sains learning outcome between a group of students who learnt by using project based learning model and the other group of students who did not learnt by using project based learning model of $5^{\text {th }}$ grade students of elementary school in the $1^{\text {th }}$ cluster of Seririt District in the academic year of 2017/2018. This research type is quasi experiment research with post test design of only control group design. The population of this research is all $5^{\text {th }}$ grade students in elementary school the $1^{\text {th }}$ cluster of Seririt District in the academic year of 2017/2018 with amount 128 student. The sampel of this study were five gread of SDN 1 Kalianget as experiment group and five grade of SDN 2 Joanyar as control group. The data collection in this research is done by using test method. The instrument that using in collection the data is objective test. The acquired data was analyzed by descriptive statistic analysis and inferential statistic. Based on the counting result of t-test, it was obtained counting $=4,51$, meanwhile tablet on the significant level $5 \%=2,02$. So that it was obtained $t_{\text {count }}>t_{\text {tabel }}$ which meant that there was significant differences the natural science between a group of students who learn by using project based learning model and the other group of students who do not learn by using project based learning model. The rate of the Sains experiment group was 21,90 and the rate of natural science control group was 15,45 . So that it could be concluded that project based learning model effected positively toward the result of Sains of the students in grade $\mathrm{V}$.
\end{abstract}

Key words: Sains learning outcome, $P B L$ 


\section{Pendahuluan}

IPA merupakan salah satu cabang ilmu pengetahuan yang memegang peranan penting dalam perkembangan IPTEKS. Pembelajaran IPA lebih menekankan pembelajaran pada peristiwa-peristiwa yang terjadi di alam. Selain itu pembelajaran IPA seharusnya diupayakan mengarah pada pencapaian tujuan IPA sehingga terbentuk pengalaman belajar yang bermakna. Pembelajaran demikian perlu dilakukan pada semua jenjang, termasuk di SD. Hal ini menandakan bahwa IPA bukan hanya penguasaan berupa fakta, konsep-konsep, atau prinsip-prinsip, tetapi juga merupakan suatu proses penemuan. pembelajaran IPA di sekolah dasar menekankan pada pemberian pengalaman belajar secara langsung dengan penggunaan dan pengembangan keterampilan proses. Tujuan pembelajaran IPA di SD adalah untuk memahami disiplin keilmuan IPA dan keterampilan berkarya (proyek) untuk menghasilkan sesuatu sebagai hasil belajar (Sukra, 2006).

Harapan pendidikan IPA yaitu proses pembelajarannya harus menekankan pada pemberian pengalaman langsung kepada siswa untuk mengembangkan kompetensi dan memahami alam sekitar secara ilmiah. "IPA juga dapat melatih anak bepikir kritis dan objektif” (Samatowa, 2010). Keberhasilan suatu pendidik tidak terlepas dari proses pembelajaran di sekolah. Proses pembelajaran dapat dianggap sebagai suatu sistem karena keberhasilannya dapat ditentukan oleh berbagai kompenen yang membentuk sistem itu sendiri. Apabila kita petakan banyak kompenen yang berpengaruh terhadap proses dan hasil belajar dari kompenen dari dalam yang secara langsung berkaitan dengan proses pembelajaran, sampai pada kompenen luar yang tidak langsung berkaitan dengan proses pembelajaran. Kompenen guru merupakan salah satu kompenen menentukan keberhasilan dalam proses pembelajaran, sebab guru merupakan ujung tombak yang secara langsung berhubungan dengan siswa sebagai objek belajar. Sehingga, pengalaman belajar yang lebih bermakna dan menarik diharapkan dapat membantu peserta didik memahami dan mengingat pengetahuan yang didapat dalam waktu yang lama (Widyantari, 2015).

Berbagai faktor dapat mempengaruhi rendahnya hasil belajar siswa seperti strategi, metode, model, intelegensi, pola asuh orang tua, minat belajar anak dan sebagainya. Khususnya di Gugus I Kecamata Seririt, faktor pertama penyebab rendahnya hasil belajar IPA siswa adalah siswa sulit mengembangkan pemahaman dalam belajar. Berdasarkan hasil wawancara yang dilakukan, siswa menyatakan bahwa siswa belum benar-benar paham dengan apa yang mereka pelajari, terbukti siswa tidak mampu mengaitkan apa yang mereka pelajari di dalam kelas dengan kegunaannya dalam kehidupan sehari-harinya. Hasil wawancara yang saya lakukan didalam kelas maupun diluar kelas pada tanggal 12 dan 13 Januari 2018 dengan guru kelas V SD di Gugus I Kecamatan Seririt, guru mengalami kesulitan mengembangkan rencana pembelajaran. Guru tidak banyak mengenal dan menerapkan model-model pembelajaran yang inovatif. Penuangan informasi dari guru kepada siswa menyebabkan siswa lebih bersifat pasif, sehingga lebih banyak menunggu sajian guru daripada mencari dan menemukan sendiri pengetahuan, keterampilan dan dikap yang mereka butuhkan.

Berdasarkan hasil observasi, diperoleh fakta pada pelaksanaan pembelajaran IPA di kelas yaitu sebagai berikut. (1) Siswa terlihat mengalami kebosanan yang ditunjukkan dengan terdapat beberapa siswa yang pandangannya tidak fokus, mengobrol dan bermain dengan teman sebangku ketika materi pelajaran IPA dijelaskan oleh guru. (2) Kemampuan siswa dalam proses ilmiah dan sikap ilmiah pada saat percobaan sangat kurang. (3) Siswa tidak berperan aktif dalam mengonstruksi pengetahuannya dan hanya diarahkan untuk menghafal materi pelajaran sehingga sebagian besar siswa tidak memahami materi yang disampaikan oleh guru. (4) Siswa jarang mendapat kesempatan untuk mengimplementasikan penemuan konsep yang telah diperoleh sehingga pengetahuan yang didapatkan siswa menjadi kurang bermakna. (5) Daya ingat siswa terhadap materi pelajaran IPA cenderung tidak lama dan pengetahuan yang didapat siswa tidak terorganisir dengan baik.

Berdasarkan hasil studi dokumentasi, menunjukkan 72,35\% siswa kelas V di Gugus I Kecamatan Seririt memiliki rata-rata nilai UAS IPA yang belum mencapai KKM. perbandingan jumlah siswa yang sudah mencapai KKM dan yang belum mencapai KKM adalah 28,63\%:71,37\%.

Tabel 1. Rata-Rata Nilai UAS IPA Kelas V Pada Semester I Di Gugus I Kecamatan Seririt

\begin{tabular}{|c|c|c|c|c|c|c|c|}
\hline \multirow[t]{2}{*}{ No } & \multirow[t]{2}{*}{ Nama Sekolah } & \multirow[t]{2}{*}{ Jumlah Siswa } & \multirow[t]{2}{*}{ KKM } & \multicolumn{2}{|c|}{ Sudah Mencapai KKM } & \multicolumn{2}{|c|}{ Belum Mencapai KKM } \\
\hline & & & & Jumlah & Persentase & Jumlah & Persentase \\
\hline 1. & SDN 1 Kalianget & 20 & 69 & 5 & $25 \%$ & 15 & $75 \%$ \\
\hline 2. & SDN 2 Kalianget & 9 & 65 & 3 & $33,30 \%$ & 6 & $66,70 \%$ \\
\hline 3. & SDN 3 Kalianget & 24 & 67 & 4 & $16,67 \%$ & 20 & $83,33 \%$ \\
\hline 4. & SDN 1 Joanyar & 25 & 65 & 10 & $40 \%$ & 15 & $60 \%$ \\
\hline 5. & SDN 2 Joanyar & 22 & 65 & 7 & $31,81 \%$ & 15 & $68,19 \%$ \\
\hline 6. & $\begin{array}{l}\text { SDN } 1 \\
\text { Tangguwisia }\end{array}$ & 28 & 67 & 7 & $25 \%$ & 21 & $75 \%$ \\
\hline
\end{tabular}

(Sumber: Wali kelas V SD di Gugus I Kecamatan Seririt) 
Pencapaian siswa masih tergolong rendah, terlihat dari lebih banyaknya siswa yang belum mampu mencapai nilai KKM, artinya nilai IPA siswa menunjukkan bahwa sebagian besar siswa memperoleh nilai yang rendah.

Rendahnya hasil belajar IPA menunjukkan bahwa perlu adanya upaya atau inovasi memperbaiki proses pembelajaran IPA. Upaya yang dapat dilakukan oleh guru untuk memperbaiki proses pembelajaran IPA adalah dengan menggunakan berbagai pendekatan, strategi, model, media, dan metode dengan tepat sesuai dengan permasalahan yang ada. Salah satu alternatif yang dipandang mampu meningkatkan hasil belajar IPA adalah pembelajaran dengan model Pembelajaran Berbasis Proyek (Project Based Learning). Menurut Purnomo (2014), Project Based Learning adalah sebuah model atau pendekatan pembelajaran yang inovatif, yang menekankan belajar kontekstual melalui kegiatan-kegiatan yang kompleks. Pembelajaran Project Based Learning ialah sebuah pembelajaran inovatif, dan lebih menekankan pada belajar kontekstual melalui kegiatan-kegiatan yang komplek. Fokus pembelajaran pada prinsip dan konsep dari suatu disiplin ilmu, melibatkan siswa melakukan investigasi pemecahan masalah dan kegiatan-kegiatan tugas-tugas bermakna, memberi kesempatan pembelajar bekerja secara mandiri dalam mengontruksi pengetahuan mereka sendiri dan menghasilkan produk nyata.

Pengoptimalan hasil belajar siswa melalui penerapan model Project Based Learning masih memerlukan kegiatan perangsang yang membuat siswa menjadi lebih ikut masuk dan berperan aktif dalam pembelajaran. Penggunaan model pembelajaran berbasis proyek (Project Based Learning), diharapkan mampu membantu siswa ikut masuk dan berperan aktif dalam pembelajaran serta mampu memahami dan mampu memecahkan masalah yang dihadapi dalam kehidupan secara mandiri maupun kelompok.

Berdasarkan uraian di atas, dipandang perlu dilakukan penelitian dengan tujuan untuk mengetahui pengaruh hasil belajar IPA antara kelompok siswa yang dibelajarkan dengan model pembelajaran berbasis proyek dan kelompok siswa yang tidak dibelajarkan dengan model pembelajaran berbasis proyek pada siswa kelas V SD di Gugus I Kecamatan Seririt Tahun Pelajaran 2017/2016.

\section{Metode}

Penelitian ini merupakan jenis penelitian eksperimen semu (quasi experiment), karena tidak semua variabel dapat dikendalikan secara ketat.Dengan rancangan nonequivalent posttest-only control group design) dapat dilihat pada gambar berikut.

\begin{tabular}{|ccc|}
\hline $\mathrm{E}$ & $\mathrm{X}$ & $\mathrm{O}_{1}$ \\
$-\mathrm{K}$ & - & $\mathrm{O}_{2}$ \\
\hline
\end{tabular}

Gambar 1.Rancangan Penelitian (dimodifikasi dari Agung, 2014)

$\mathrm{E} \quad=$ kelompok eksperimen

$\mathrm{K} \quad$ =kelompok kontrol

$\mathrm{O}_{1} \quad=$ kelompok eksperimen setelah ada perlakuan (post-test)

$\mathrm{O}_{2} \quad=$ kelompok kontrol yang tidak diberikan perlakuan

$\mathrm{X} \quad$ = perlakuan (treatment) dengan model pembelajaran complete sentence berbantuan media audio

- $\quad$ = tidak adanya perlakuan (treatment) dengan model pembelajaran complete sentence berbantuan media audio

Pelaksanaan penelitian ini terdiri dari tiga tahap yakni tahap persiapan, tahap pelaksanaan, dan tahap pelaporan. Tahap persiapan terdiri dari merancang perangkat pembelajaran dan instrumen yang digunakanuntukpenelitian, mengonsultasikan perangkat pembelajaran dan instrumen dengan pembimbing dan pakar, menguji instrumen yang digunakan untuk penelitian, melakukan analisis uji instrumen, merevisi instrumen penelitian yang telah dilakukan. Pada tahap pelaksanaanpertemuandiadakan sebanyak 8 kali pertemuan. 7 kali pertemuan untuk memberikan treatment dan 1 kali pertemuan untuk pemberian posttest. Langkah-langkah yang dilakukan pada tahap ini adalah memberikan perlakuan model pembelajaran pembelajaran berbasis proyek pada kelas eksperimen dan pembelajaran dengan tidak menggunakan model pembelajaran pembelajaran berbasis proyek pada kelas kontrol, kemudian mengadakan posttest pada kelas eksperimen dan kelas kontrol. Pada tahap pelaporan yang dilakukan adalah melakukan analisis data dilanjutkan 
dengan pengujian hipotesis sesuai data yang diperoleh dan menyusun laporan penelitian sesuai dengan analisis data yang didapatkan.

Tempat pelaksanaan penelitian ini adalah SD Gugus I Kecamatan Seririt. Waktu penelitian ini pada semester genap tahun pelajaran 2017/2018. Populasi dalam penelitian ini adalah semua siswa kelas V di SD Gugus I Kecamatan Seririt yang berjumlah 6 sekolah dasar. Jumlah seluruh anggota populasi adalah 128 siswa. Banyaknya populasi dan sebarannya dapat dilihat pada table 2. berikut.

Tabel 2.Populasi Penelitian

\begin{tabular}{lll}
\hline No & Nama Sekolah Dasar & Jumlah Siswa \\
\hline 1 & SD N 1 Kalianget & 20 \\
\hline 2 & SD N2 Kalianget & 9 \\
\hline 3 & SD N 3 Kalianget & 24 \\
\hline 4 & SDN 1 Joanyar & 25 \\
\hline 5 & SD N 2 Joanyar & 22 \\
\hline 6 & SD N 1 Tangguwisia & 28 \\
\hline Jumlah & 128 \\
\hline
\end{tabular}

Pemilihan sampel dalam penelitian ini menggunakan teknik random sampling yaitu pengambilan sampel anggota populasi secara acak tanpa memperhatikan strata yang ada.

Tahap pertama dilakukan uji kesetaraan terhadap enam sekolah dasar tersebut. Penyetaraan sampel dihitung berdasarkan nilai Ulangan Akhir Semester IPA kelas V Semester I tahun pelajaran 2017/2018. Untuk menghitung kesetaraan kelompok sampel digunakan rumus uji ANAVA.

Setelah memperoleh hasil perhitungan uji kesetaraan, selanjutnya keenam SD itu dirandom untuk menentukan kelas eksperimen dan kelas kontrol. Dalam pemilihan kelas eksperimen dan kelas kontrol dilakukan dengan teknik undian. Melalui random sampling ersebut ditetapkan kelas V di SD Negeri 1 Kalianget yang berjumlah 20 orang sebagai kelompok eksperimen yang diberi perlakuan berupa pembelajaran berbasis proyek dan kelas V di SD Negeri 2 Joanyar yang berjumlah 22 orang sebagai kelompok kontrol yang diberi perlakuan berupa bukan model pembelajaran berbasis proyek.

Instrumen pengumpulan data yang digunakan dalam penelitian ini adalah berupa tes objektif. Soal objektif yang digunakan terdiri dari 30 butir soal. Untuk menentukan butir soal instrumen tersebut layak untuk diberikan terhadap kelompok sampel terlebih dahulu dilakukan uji coba. Uji coba tes hasil belajar IPA meliputi: validitas butir tes, reliabilitastes tes, daya beda tes, dan tingkat kesukaran tes.Tes yang akan diujikan adalah tes objektif yang terdiri atas 40 butir soal yang diberikan kepada 54 testee. Hasil analisis menunjukkan 32 butir tes yang valid dengan reliabilitas 0,80 ini berarti tes yang diujicobakan tergolong tinggi. Analisis data dalam penelitian ini dilakukan dalam 2 tahap. Pada tahap pertama dilakukan analisis deskriptif, tahap kedua dilanjutkan dengan analisis inferensial. Statistik deskriptif berfungsi untuk mengelompokkan data, menggarap, serta menyajikan hasil olahan. Statistik deskriptif yang digunakan dalam penelitian ini yaitu rat-rata (mean), median, modus. Sedangkan statistik inferensial berfungsi untuk menggeneralisasikan hasil penelitian yang dilakukan oleh subjek penelitian. Statistic inferensial ini digunakan untuk menguji hipotesis melalui uji-t yang diawali dengan analisis prasyarat yaitu uji normalitas sebaran data dan uji homogenitas varians.

\section{Hasil dan Pembahasan}

Pengukuran dilakukan setelah kelompok eksperimen diberikan perlakuan model pembelajaran Berbasis Proyek (Project Based Learning) dan kelompok kontrol tidak diberikan perlakuan model pembelajaran Berbasis Proyek (Project Based Learning), sebanyak tujuh kali pertemuan dengan materi ajar yang sama. Analisis data dilakukan pada masing-masing kelas yaitu kelas eksperimen dan kelas kontrol. Adapun hasil analisis data statistik deskriptif disajikan pada Tabel 3.

Tabel 3. Analisis Data dengan Statistik Deskriptif

\begin{tabular}{ccc}
\hline Statistik & Kelompok Eksperimen & Kelompok Kontrol \\
\hline Mean & 21,9 & 15,45 \\
Median & 22,87 & 14,07 \\
Modus & 23.83 & 12,5 \\
Standar Deviasi & 4,23 & 5,22 \\
Varians & 17,85 & 27,21 \\
\hline
\end{tabular}


Pada kelompok siswa yang dibelajarkan dengan model Pembelajaran Berbasis Proyek (Project Based Learning) banyak siswa yang mendapat nilai rata-rata kelompok (21,9). Jadi, rata-rata hitung data hasil belajar IPA kelompok siswa yang dibelajarkan dengan model Pembelajaran Berbasis Proyek (Project Based Learning) dikategorikan tinggi. Berdasarkan data pada Tabel 1, data hasil belajar kelompok eksperimen disajikan dalam bentuk kurva polygon, seperti Gambar 1.

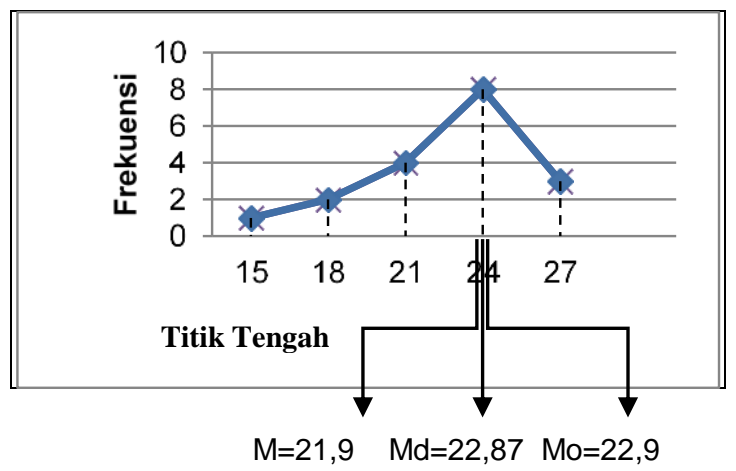

Gambar 1. Kurva Poligon Data Hasil Belajar IPA Kelompok Eksperimen

Berdasarkan kurva polygon data hasil belajar IPA kelompok siswa yang dibelajarkan dengan model Pembelajaran Berbasis Proyek (Project Based Learning), dapat diketahui bahwa modus lebih besar dari median dan median lebih besar dari mean $(\mathrm{Mo}>\mathrm{Md}>\mathrm{M})$. Dengan demikian, kurva diatas adalah kurva juling negatif. Artinya, sebagian besar skor cenderung tinggi.

Sedangkan pada kelompok siswa yang tidak dibelajarkan dengan model Pembelajaran Berbasis Proyek (Project Based Learning) banyak siswa yang mendapat nilai sekitar rata-rata kelompok $(15,45)$. Jadi, rata-rata hitung data hasil belajar IPA kelompok siswa yang tidak dibelajarkan dengan model Pembelajaran Berbasis Proyek (Project Based Learning) dikategorikan sedang. Data hasil belajar IPA siswa kelas kontrol disajikan pada Gambar 2.

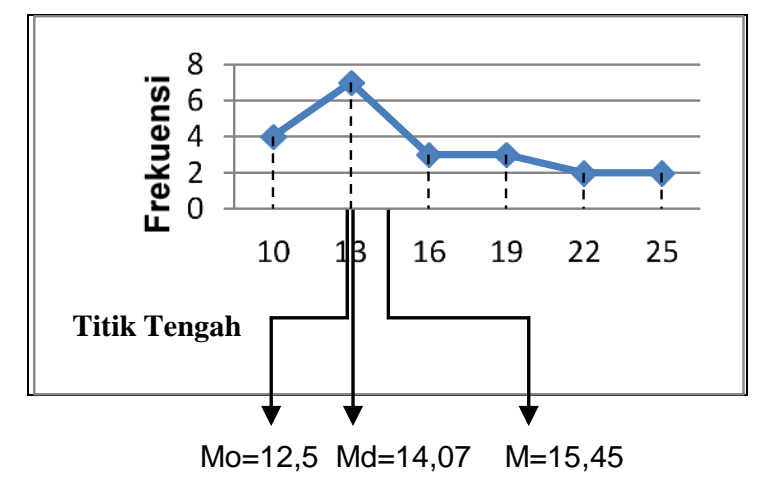

Gambar 2. Kurva Polygon Data Hasil Belajar IPA Siswa Kelompok Kontrol

Berdasarkan kurva polygon data hasil belajar IPA kelompok siswa yang tidak dibelajarkan dengan model Pembelajaran Berbasis Proyek (Project Based Learning) diatas, dapat diketahui bahwa modus lebih kecil dari median dan median lebih kecil dari mean $(\mathrm{Mo}<\mathrm{Md}<\mathrm{M})$. Dengan demikian, kurva diatas adalah kurva juling positif. Artinya, sebagian besar skor cenderung rendah.

Setelah melakukan analisis statistik deskriptif, selanjutnya dilakukan uji prasyarat untuk menguji hipotesis. Uji prasyarat yang dilakukan adalah uji normalitas dan homogenitas.

Uji normalitas data dilakukan terhadap hasil belajar IPA kelompok eksperimen dan kontrol. Berdasarkan analisis data yang dilakukan, dapat disajikan hasil uji normalitas sebaran data keterampilan menyimka bahasa Indonesia kelompok eksperimen dan kontrol pada Tabel 4 berikut ini. 


\begin{tabular}{lllll}
\hline No. & Data Sampel & $\chi^{2}$ hitung & $\chi^{2}$ tabel $(5 \%)$ & Status \\
\hline 1 & Hasil belajar IPA kelompok eksperimen & 4,455 & 5,591 & Normal \\
\hline 2 & Hasil belajar IPA kelompok kontrol & 4,974 & 7,815 & Normal \\
\hline
\end{tabular}

Berdasarkan hasil perhitungan dengan menggunakan rumus Chi Kuadra, diperoleh $\chi^{2}$ hitung skor keterampilan menyimak bahasa Indonesia siswakelompok eksperimen adalah 4,455, sedangkan $\chi^{2}$ tabel dengan taraf signifikansi $5 \%$ dan $\mathrm{dk}=2$ adalah 5,591. Hal ini berarti, $\chi^{2}$ hitung skor hasil belajar IPA kelompok eksperimen lebih kecil dari $\chi^{2}{ }_{\text {tabel }}\left(\chi^{2}\right.$ hitung $<\chi^{2}{ }_{\text {tabel }}$ ), sehingga data hasil belajar IPA kelompok eksperimen berdistribusi normal. Selanjutnya, $\chi^{2}{ }^{\text {hitung }}$ skor hasil belajar IPA kelompok kontrol adalah 4,974 dan $\chi^{2}$ tabel dengan taraf signifikansi $5 \% \mathrm{dan} \mathrm{dk}=3$ adalah 7,815. Hal ini berarti, $\chi^{2}$ hitung data hasil belajar IPA kelompok kontrol lebih kecil dari $\chi^{2}$ tabel $\left(\chi^{2}{ }_{\text {hitung }}<\chi^{2}\right.$ tabel $)$, sehingga data hasil belajar IPA kelompok kontrol berdistribusi normal.

Selanjutnya, uji homogenitas dilakukan terhadap varians pasangan antara kelompok eksperimen dan kelompok kontrol. Hasil uji homogenitas varians antara kelompok eksperimen dan kelompok kontrol disajikan pada tabel berikut ini.

Tabel 5. Hasil Uji Homogenitas Kelompok Eksperimen dan Kontrol

\begin{tabular}{cccc}
\hline Sumber Data & $\mathbf{F}_{\text {hit }}$ & $\begin{array}{c}\mathbf{F}_{\text {tab }} \text { dengan Taraf } \\
\text { Signifikansi 5\% }\end{array}$ & Status \\
\hline $\begin{array}{c}\text { Eksperimen } \\
\text { Kontrol }\end{array}$ & 1,52 & 2,11 & Homogen \\
\hline
\end{tabular}

Berdasarkan tabel di atas, diketahui $\mathrm{F}_{\text {hitung }}$ skor hasil belajar IPA kelompok eksperimen dan kontrol adalah 1,52, sedangkan $\mathrm{F}_{\text {tabel }}$ dengan $\mathrm{dk}_{\text {pembilang }}=19$ dan $\mathrm{dk}_{\text {penyebut }}=21$ pada taraf signifikansi $5 \%$ adalah 2,11. Hal ini berarti, varians data hasil belajar IPA kelompok eksperimen dan kontrol adalah homogen.

Berdasarkan uji prasyarat analisis data, diperoleh bahwa data hasil post-test kelompok eksperimen dan kelompok kontrol adalah normal dan homogen. Setelah diperoleh hasil dari uji prasyarat analisis data, dilanjutkan dengan pengujian hipotesis penelitian $\left(\mathrm{H}_{1}\right)$ dan hipotesis nol $\left(\mathrm{H}_{0}\right)$. Pengujian hipotesis tersebut dilakukan dengan menggunakan uji-t dengan rumuspolled varians dengan kriteria $\mathrm{H}_{0}$ tolak jika $t_{\text {hit }}>t_{\text {tab }}$ dan $\mathrm{H}_{0}$ terima jika $t_{\text {hit }}<t_{\text {tab. }}$. Rangkuman hasil perhitungan uji-t antara kelompok eksperimen dan kelompok kontrol disajikan pada tabel 6 di berikut ini.

Tabel 6.Ringkasan Hasil Uji Hipotesis

\begin{tabular}{ccccccc}
\hline Kelompok & $\mathbf{N}$ & $\mathbf{D b}$ & $\operatorname{Mean}(\bar{x})$ & $\mathbf{s}^{\mathbf{2}}$ & \multirow{2}{*}{$\mathbf{t}_{\text {hitung }}$} & $\mathbf{t}_{\text {tabel }}$ \\
\hline Eksperimen & 20 & \multirow{2}{*}{40} & 21,90 & 17,85 & 4,51 & 2,02 \\
Kontrol & 22 & & 15,45 & 27,21 & & \\
\hline
\end{tabular}

Berdasarkan tabel di atas, tampak bahwa $\mathrm{t}_{\text {hitung }}$ sebesar 4,51 , sedangkan, $\mathrm{t}_{\text {tabel }}$ dengan $\mathrm{db}=40$ pada taraf signifikansi 5\% adalah 2,02. Hal ini berarti, $t_{\text {hitung }}$ lebih besar dari $t_{\text {tabel }}\left(t_{\text {hitung }}>t_{\text {tabel }}\right)$ sehingga $\mathrm{H}_{0}$ ditolak dan $\mathrm{H}_{1}$ diterima. Dengan demikian, dapat diinterpretasikan bahwa terdapat perbedaan yang signifikan pada hasil belajar IPA antara siswa yang belajar dengan model pembelajaran berbasis proyek (project based learning) dan siswa yang tidak belajar dengan model pembelajaran berbasis proyek (project based learning) pada siswa kelas V SD di Gugus I Kecamatan Seririt Tahun Pelajaran 2017/2018.

Perbedaan perlakuan yang diterapkan pada kelompok eksperimen dan kontrol dalam penelitian ini menunjukkan pengaruh yang berbeda pada hasil belajar IPA siswa. Hal ini dapat dilihat dari hasil belajar IPA siswa. Secara deskriptif, hasil belajar IPA kelompok siswa yang dibelajarkan dengan model pembelajaran berbasis proyek lebih tinggi dibandingkan dengan kelompok siswa yang tidak dibelajarkan dengan model Pembelajaran Berbasis Proyek (Project Based Learning). Rata-rata skor hasil belajar IPA kelompok siswa yang dibelajarkan dengan model Pembelajaran Berbasis Proyek (Project Based Learning) adalah 21,90 berada pada kategori tinggi sedangkan rata-rata skor kelompok siswa yang tidak dibelajarkan dengan model Pembelajaran Berbasis Proyek (Project Based Learning) adalah 15,45 berada pada kategori sedang. 
Berdasarkan analisis data menggunakan uji-t, diketahui $t_{\text {hitung }}=4,51$ dan $t_{\text {tabel }}=2,02$. Hasil perhitungan tersebut menunjukkan bahwa $t_{\text {hitung }}$ lebih besar dari $t_{\text {tabel }}\left(t_{\text {hitung }}>t_{\text {tabel }}\right)$ sehingga hasil penelitaian signifikan . hal ini berrti terdapat pengaruh yang signifikan terhadap hasil belajar kelompok siswa yang dibelajarakan dengan model Pembelajaran Berbasis Proyek (Project Based Learning) dan kelompok siswa yang tidak dibelajarakan dengan model Pembelajaran Berbasis Proyek (Project Based Learning) pada siswa kelas V SD di Gugus I Kecamatan Seririt Tahun Pelajaran 2017/2018.

Hasil penelitian ini telah membuktikan hipotesis yang diajukan, yaitu terdapat peerbedaan yang signifikan hasil belajar IPA antara kelompok siswa yang dibelajarkan menggunakan model Pembelajaran Berbasis Proyek (Project Based Learning) dan kelompok siswa yang tidak dibelajarkan menggunakan model Pembelajaran Berbasis Proyek (Project Based Learning) pada siswa kelas V SD di Gugus I Kecamatan Seririt Tahun Pelajaran 2017/2018. Hal tersebut dipengaruhi oleh beberapa hal yaitu.

Pertama, model pembelajaran berbasis proyek (project based learning) menjadikan siswa aktif dalam pembelajaran. Siswa aktif merupakan hal yang menandakan pembelajaran berjalan dengan baik. Pembelajaran yang melibatkan aktivitas siswa secara aktif akan mampu meningkatkan daya ingat serta keterampilan siswa dalam memecahkan suatu permasalahan. Melalui pembelajaran aktif, siswa akan terlibat secara langsung dalam pembelajaran. Apabila siswa aktif dalam pembelajaran, siswa akan memperoleh pengalaman langsung, yang menjadikan pembelajaran menjadi lebih bermakna dan siswa akan bersemangat dalam belajar. Hal ini sejalan dengan pendapat Hollingswort dan Lewis (dalam Riastini 2016:48) yang menyatakan siswa belajar aktif ketika mereka terus menerus terlibat baik secara mental ataupun fisik. Pembelajaran aktif itu penuh semangat, hidup, giat, berkesinambungan, kuat dan efektif. Pembelajaran aktif melibatkan pembelajaran yang terjadi ketika siswa bersemangat, siap secara mental dan bisa memahami apa yang dialami.

Kedua, model pembelajaran berbasis proyek dapat menciptakan interaksi antar siswa. Hal ini terlihat pada saat melakukan kegiatan proyek. Dengan adanya bimbingan dari guru , guru juga memberikan arahan bahwa kegiatan proyek yang dilakukan berkaitan dengan kejadian alam yang terjadi dilingkungan. Begitu pula interaksi dalam kelompok lebih kondusif. Hal ini sejalan dengan penelitian Dewi (2013) yang menyatakan interaksi antar siswa dengan siswa, siswa dengan guru lebih meningkat dengan adanya diskusi kelompok. Melalui diskusi kelompok siswa dapat menyampaikan pendapat atau bertukar informasi.

Ketiga, model pembelajaran berbasis proyek, mampu meningkatkan keterlibatan siswa dalam pembelajaran. Hal ini disebabkan karena model pembelajaran berbasis proyek menekankan kegiatan pembelajaran yang berpusat kepada siswa dengan mengarahkan siswa melakukan tugas praktik langsung yang berhubungan dengan lingkungan. Dengan mengikuti langkah kegiatan dengan baik sehingga dapat mengahasilkan sebuah produk dan menyampaikan hasil kegiatan didepan kelas. Hal ini sejalan dengan pendapat Andana (2014) yang menyatakan keterlibatan langsung siswa dalam pembelajaran tersebut, dapat memberikan kesempatan kepada siswa untuk menggunakan pengetahuan yang telah dimiliki atau pengetahuan awal siswa pada kegiatan berinteraksi antar kelompok serta dapat juga meningkatkan keterampilan ilmiah siswa dalam melakukan nsuatu tugas proyek. Selain itu pembelajaran yang dilakukan akan lebih bermakna, karena melalui tugas proyek yang diberikan memberikan pengalaman berdasarkan kegiatan yang telah dilakukan sendiri, yang nantinya berdampak pada meningkatnya hasil belajara siswa.

\section{Simpulan}

Berdasarkan hasil penelitian dan pembahasan, dapat disimpulkan bahwa terdapat pengaruh yang signifikan pada hasil belajar IPA antara siswa yang belajar dengan model pembelajaran berbasis proyek (project based learning) dan siswa yang tidak belajar dengan model pembelajaran berbasis proyek (project based learning) pada siswa kelas V SD di Gugus I Kecamatan Seririt Tahun Pelajaran 2017/2018. Hal tersebut diperoleh dari hasil penghitungan uji- $t$, $t_{\text {hit }}$ sebesar 4,51 , sedangkan, $t_{t a b}$ (dengan $\mathrm{db}=40$ dan taraf signifikansi $5 \%$ ) adalah 2,02. Hal ini berarti, $t_{\text {hit }}$ lebih besar dari $t_{\text {tab }}\left(t_{\text {hit }}>t_{\text {tab }}\right)$, sehingga $H_{0}$ ditolak dan $H_{1}$ diterima.Dari ratarata $(\bar{X})$, diketahui $(\bar{X})$ kelompok eksperimen sebesar 21,90 dan $(\bar{X})$ kelompok kontrol sebesar 15,45. Hal ini berarti $(\bar{X})$ eksperimen $>(\bar{X})$ kontrol. Dengan demikian, model pembelajaran berbasis proyek (project based learning) berpengaruh terhadap hasil belajar IPA pada siswa kelas V SD di Gugus I Kecamatan Seririt tahun pelajaran 2017/2018.

Saran yang dapat disampaikan berdasarkan penelitian yang telah dilakukan yaitu (1) kepada guru disarankan untuk menerapkan model pembelajaran Berbasis Proyek (Project Based Learning) dalam rangka memperbaiki kualitas pembelajaran di kelas dan mengembangkan hasil belajar IPA siswa. Hal ini karena dalam model pembelajaran Berbasis Proyek (Project Based Learning) akan membantu siswa dalam memecahkan masalah dengan prosedur-prosedur penemuan dalam ilmu pengetahuan serta mendapat catatan yang menarik sehingga membantu siswa lebih mudah mengingat serta memahami materi yang sedang dipelajari. Selain itu, guru sebaiknya lebih sering membentuk kelompok diskusi dalam setiap pembelajaran, agar peserta didik terbiasa 
memecahkan permasalahan maupun soal-soal yang berkaitan dengan materi melalui diskusi dengan berkelompok.

(2) Kepada siswa disarankan untuk menemukan konsep-konsep IPA secara mandiri, aktif dan kreatif untuk dapat meningkatkan kemampuan pemahaman konsep sehingga akan berimplikasi pada pencapaian hasil belajar yang lebih optimal. Penelitian ini terbatas membahas pada materi IPA yaitu tentang sifat-sifat cahaya dan batuan, melibatkan sampel terbatas pada satu gugus, dan mengukur satu variabel yaitu hasil belajar IPA. Kepada peneliti lain, disarankan agar mengadakan penelitian lebih lanjut tentang model pembelajaran Berbasis Proyek (Project Based Learning)dalam bidang ilmu IPA maupun bidang ilmu lainnya. Pada materi-materi IPA yang lain dan lebih luas, melibatkan sampel yang lebih besar serta melibatkan variabel-variabel yang lain sehingga mendapatkan hasil yang lebih optimal. (3) Dengan dilakukannya penelitian ini, diharapkan peneliti lain dapat melakuakan penelitian sejenis lebih lanjut tentang model pembelajaran berbasis proyek (project based learning) dalam bidang IPA maupun bidang ilmu lainnya agar memperhatikan kendala-kendala yang dialami dalam penelitian ini sebagai bahan pertimbangan untuk perbaikan dan penyempurnaan penelitian yang akan dilaksanakan. (4) Sekolah hendaknya selalu mensosialisasikan aktivitas-aktivitas pembelajaran yang inovatif kepada guru sehingga para guru memiliki wawasan yang cukup mengenai aktivitas-aktivitas pembelajaran yang inovatif agar nantinya dapat diterapkan di kelas masing-masing untuk meningkatkan keaktifan siswa

\section{Daftar Pustaka}

Agung, Anak Agung Gede. 2014. Buku Ajar Metodologi Penelitian Pendidikan. Malang: Adiya Media Publishing.

Agustiana, I Gusti Ayu Tri dan I Nyoman Tika. 2013. Konsep Dasar IPA . Yogyakarta: Ombak.

Andana, I Made Edi. 2014. Pengaruh Model Pembelajaran Berbasis Proyek Terhadap Hasil Belajar IPA Siswa Kelas IV SD di Gugus V Kecamatan Tegalalang. Jurnal Mimbar PGSD Universitas Pendidikan Ganesha, Volume 2.

Dewi, Ni Ketut Nik Aris Sandi. 2013. Pengaruh Model Pembelajaran Berbasis Proyek (Project Based Learning) Terhadap Hasil Belajar IPA Siswa Kelas IV SD N 8 Banyuning. Jurnal Mimbar PGSD Universitas Pendidikan Ganesha, Volume 1.

Jayadiningrat, M. G., \& Ati, E. K. (2018). Peningkatan Keterampilan Memecahkan Masalah Melalui Model Pembelajaran Problem Based Learning (PBL) Pada Mata Pelajaran Kimia. Jurnal Pendidikan Kimia Indonesia, 2(1), 1-7.

Riastini, Putu Nanci, dkk. 2016. Pembelajaran IPA SD. Singaraja : Universitas Pendidikan Ganesha.

Purnomo, Eko Andy. 2014. Peningkatan Kemampuan Pemecahan Masalah Melalui Model Pembelajaran Ideal Problem Solving Berbasis Project Based Learning. JKPM, Volume 1.

Samatowa, Usman. 2010. Pembelajaran IPA Di Sekolah Dasar. Jakarta: PT Indeks.

Sukra, Warpala. 2006. Pengaruh Pendekatan Pembelajaran dan Strategi Belajar Kooperatif yang Berbeda Terhadap Pemahaman dan Keterampilan Berpikir Kritis dalam Pembelajaran IPA SD. Jurnal Universitas Negeri Malang, Volume 1.

Widyantari, Sri. 2015. Pengaruh Model Pembelajaran Berbasis Proyek Terhadap Kemampuan Berpikir Kritis IPA Siswa Kelas V. Jurnal Mimbar PGSD Universitas Pendidikan Ganesha, Volume 3. (diakses tanggal 3 Januari 2018). 